This item was submitted to Loughborough's Research Repository by the author.

Items in Figshare are protected by copyright, with all rights reserved, unless otherwise indicated.

\title{
Recent trends in U.S. flood risk
}

\section{PLEASE CITE THE PUBLISHED VERSION}

http://dx.doi.org/10.1002/2016GL071199

\section{PUBLISHER}

(c) American Geophysical Union. Published by Wiley

\section{VERSION}

VoR (Version of Record)

\section{PUBLISHER STATEMENT}

This work is made available according to the conditions of the Creative Commons Attribution-NonCommercialNoDerivatives 4.0 International (CC BY-NC-ND 4.0) licence. Full details of this licence are available at: https://creativecommons.org/licenses/by-nc-nd/4.0/

\section{LICENCE}

CC BY-NC-ND 4.0

\section{REPOSITORY RECORD}

Slater, Louise, and Gabriele Villarini. 2019. "Recent Trends in U.S. Flood Risk". figshare. https://hdl.handle.net/2134/23983. 


\section{Geophysical Research Letters}

\author{
RESEARCH LETTER \\ 10.1002/2016GL071199 \\ Key Points: \\ - We propose the first quantification of \\ changes in inundation frequency \\ above action, minor, moderate, and \\ major flood stage \\ - We find stark regional patterns of \\ changing flood risk that are consistent \\ above all four flood categories \\ - These patterns are strongly \\ preconditioned by the long-term \\ wetness and the water storage \\ availability
}

Supporting Information:

- Supporting Information S1

Correspondence to:

L. J. Slater,

louise-slater@uiowa.edu

\section{Citation:}

Slater, L. J., and G. Villarini (2016), Recent trends in U.S. flood risk, Geophys. Res. Lett., 43, doi:10.1002/2016GL071199.

Received 13 SEP 2016 Accepted 10 NOV 2016 Accepted article online 12 NOV 2016

C2016. American Geophysical Union. All Rights Reserved.

\section{Recent trends in U.S. flood risk}

\author{
Louise J. Slater ${ }^{1}$ and Gabriele Villarini ${ }^{1}$ \\ ${ }^{1}$ IIHR-Hydroscience and Engineering, University of lowa, lowa City, lowa, USA
}

Abstract Flooding is projected to become more frequent as warming temperatures amplify the atmosphere's water holding capacity and increase the occurrence of extreme precipitation events.

However, there is still little evidence of regional changes in flood risk across the USA. Here we present a novel approach assessing the trends in inundation frequency above the National Weather Service's four flood level categories in 2042 catchments. Results reveal stark regional patterns of changing flood risk that are broadly consistent above the four flood categories. We show that these patterns are dependent on the overall wetness and potential water storage, with fundamental implications for water resources management, agriculture, insurance, navigation, ecology, and populations living in flood-affected areas. Our findings may assist in a better communication of changing flood patterns to a wider audience compared with the more traditional approach of stating trends in terms of discharge magnitudes and frequencies.

\section{Introduction}

In water year 2016 alone (1 October 2015 to 30 September 2016), the United States witnessed major floods spanning Missouri, the South and Midwest, Texas, Oklahoma, West Virginia, Maryland, and Louisiana. Many of these floods were catastrophic, reaching unprecedented flood levels (Figure 1), and affecting hundreds of thousands of people. Such flood-related disasters are of global concern with the increasing concentration of population in urban settlements [Jha et al., 2012] and the heightened exposure of assets to flood damage. In the USA, the cost of flooding is extensive, with total insured values in the National Flood Insurance program reaching almost \$1.28 trillion for the period of 2001-2012 [Kousky and Michel-Kerjan, 2015].

The National Weather Service (NWS) uses four categories to communicate the severity of water surface elevation: action (requiring mitigation action in preparation for more substantial flooding), minor (with minimal or no property damage, but possibly some public threat), moderate (with some inundation of structures and roads and evacuations of people and/or property transfer to higher ground), and major (with extensive inundation, significant evacuations, or property transfer) [NOAA National Weather Service, 2012]. These categories are numeric thresholds that are determined at each gauging site (Figure 1) to monitor and forecast flood risk. We define the risk as the interaction of the flood hazard (probability) and the vulnerability [e.g., Merz et al., 2012] based on the four NWS flood categories. Thus, we use historical gage height (i.e., stage) records from the U.S. Geological Survey (USGS) to understand how the local flood risk is changing over time: in the case of Louisiana, the frequency of flood days has been progressively increasing above action, minor, and moderate flood categories (Figure 1a), while in South Carolina it has actually been decreasing (Figure 1b).

Changes in the frequency of flooding may occur through a combination of factors, including shifts in atmospheric conditions (e.g., magnitude, type, seasonality, and phase of precipitation), snowmelt patterns, antecedent soil moisture, land use and land cover (e.g., urbanization and agriculture), and anthropogenic modifications of the water cycle (e.g., management, extractions, dams, and diversions). Flood trends are typically investigated using discharge as a proxy for flood magnitudes [Milly et al., 2002, 2005; Vogel et al., 2011; Hirsch and Ryberg, 2012; Mallakpour and Villarini, 2015; Slater et al., 2015; Archfield et al., 2016]. However, classic trend-detection approaches using annual flow maxima [e.g., Mallakpour and Villarini, 2015] or regional flow averages [e.g., Archfield et al., 2016] may actually conceal any changes in small or local flood events. Additionally, any changes in a river channel's capacity (i.e., the depth, width, and roughness) may significantly alter the frequency of local flooding above set flood levels (even in the absence of any changes in discharge) [Slater et al., 2015], so trends in flood frequency that are measured using discharge and gage height time series can be markedly different [Slater, 2016], especially in locations that have experienced major changes in channel capacity due to urbanization/regulation [e.g., Stover and Montgomery, 2001]. 

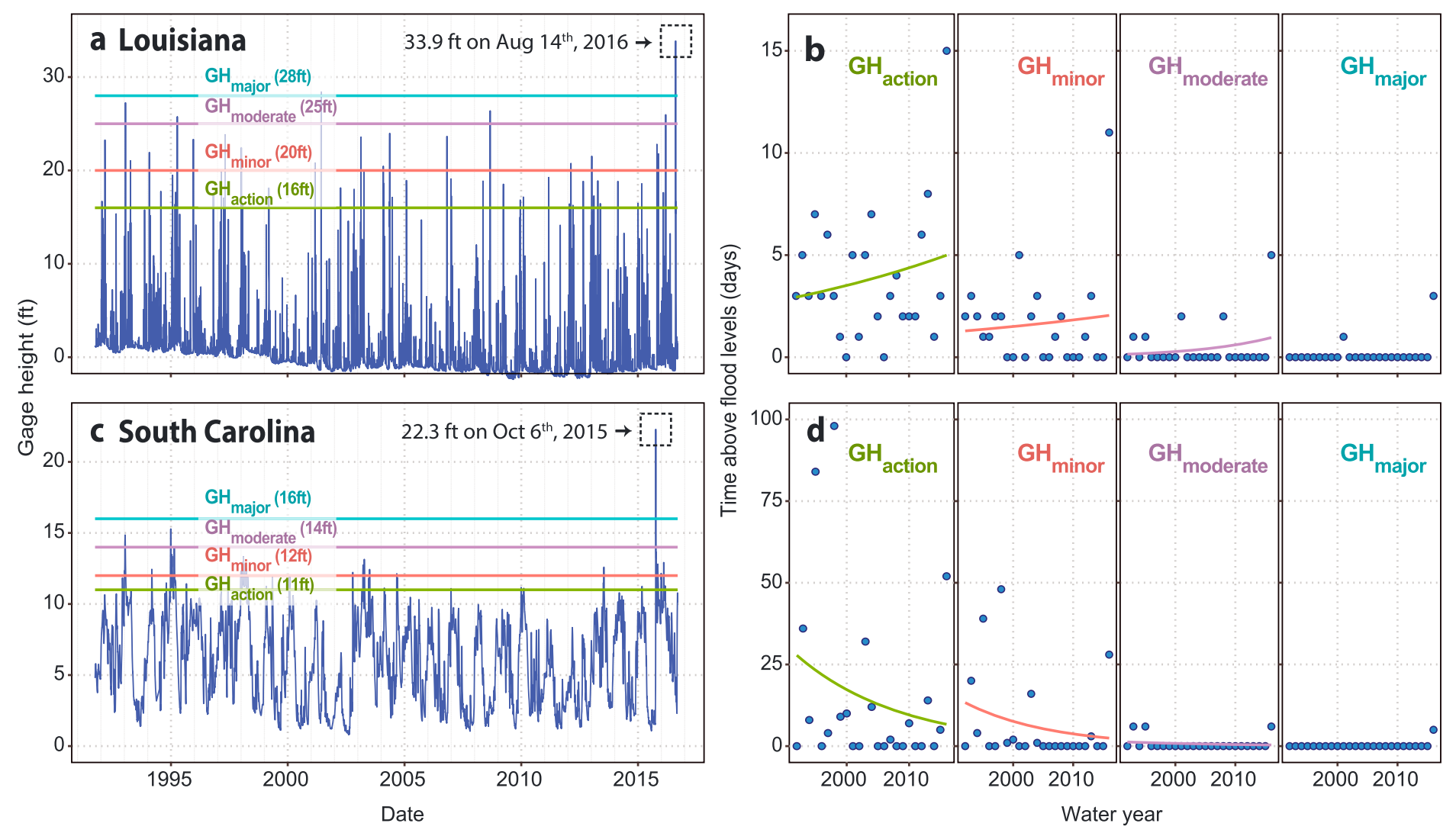

Figure 1. Trends in flood frequency above action, minor, moderate, and major flood levels. (top row) Comite River near Comite, Louisiana (USGS site 07378000). (bottom row) Black River at Kingstree, South Carolina (02136000). (a and c) Time series of mean daily gage height (GH, in feet), with the four NWS flood levels $\left(\mathrm{GH}_{\text {action, }}, \mathrm{GH}_{\text {minor, }}, \mathrm{GH}_{\text {moderate, }}\right.$ and $\left.\mathrm{GH}_{\text {major }}\right)$ indicated as horizontal color lines. (b and d) Trends in the number of days per water year where gage height exceeded the four flood levels. For illustrative purposes, the time series shown here include water year 2016 and incomplete years ( $<330$ days). The color lines in Figures $1 \mathrm{~b}$ and $1 \mathrm{~d}$ represent the rate of occurrence parameter based on Poisson regression (section 2).

Here we specifically use only the most recently obtained NWS flood categories (and not changing flood levels) to investigate how the frequency of flooding is changing at those given levels over time, irrespective of any changes in the capacity of the river channel [Slater et al., 2015; Slater, 2016]. By tying gage height with the NWS flood categories $\left(\mathrm{GH}_{\text {action, }} \mathrm{GH}_{\text {minor, }} \mathrm{GH}_{\text {moderate, }}\right.$ or $\mathrm{GH}_{\text {major }}$ ) it becomes possible to investigate the practical impacts of changes in precipitation on flooding at the local scale, across the continental USA. Further, corrected stage measurements are inherently more precise for this purpose than the discharge estimates that are obtained from the stage-discharge rating relationships [Carter and Davidian, 1968], particularly during high flows.

\section{Materials and Methods}

\subsection{Gage Height Data}

We listed all of the USGS stream gages [United States Geological Survey, 2015] for which NWS flood categories were documented and downloaded all available daily gage height data (1985-2015) from the National Water Information System (NWIS-web). When little or no data were available online, we contacted the USGS Water Science Centers and received provisional gage height data (Table S1 in the supporting information) in instantaneous form (15 to $60 \mathrm{~min}$ increments), with the caveat that they might contain erroneous values. The majority of these sites are streams, with some lakes, reservoirs, and tidally influenced sites, and a mix of regulated and unregulated sites. We obtained gage descriptions from online USGS Water Year Reports to detect any changes in the gage location or datum, and thus discard any data preceding a change in gage location (Table S2), and/or correct any changes in datum 
by shifting the time series prior to the date of the change. Any apparent shifts in gage height minima or in the gage height-discharge relationship were investigated as potential changes in datum or gage/measurement location. Any extreme, visibly erroneous minima and maxima were removed, and sites with data judged unreliable were discarded (Table S2). In many states, electronic gage height records have only been stored since 2000/2001. Therefore, we carried out sensitivity tests with a minimum of $14,15,20$, and 25 complete (300+ daily measurements) water years and find similar patterns irrespective of record length (Figure S1 in the supporting information). Water year 1985 was chosen as the starting date because only a minority of gage height records extend before then (Figure S2). While these records may seem short in comparison with some discharge records, our aim is not to discuss or detect any long-term climate-related changes in flooding but to show how rapidly the local flood risk can change above NWS categories.

\subsection{Trends in Flood Frequency}

To assess flood frequency, we follow a peak over threshold approach and compute the number of days per water year in which the mean daily gage height exceeded or equaled the $\mathrm{GH}_{\text {action, }} \mathrm{GH}_{\text {minor }}$, $\mathrm{GH}_{\text {moderate, }}$ or $\mathrm{GH}_{\text {major }}$ thresholds. At each site, trends in these quantities are detected using a Poisson regression model because the data are discrete and bounded at zero (Figure 1b). Trends are considered significant at the $5 \%$ level; however, sensitivity tests performed for $p \leq 0.10, p \leq 0.01$, and $p<0.001$ reveal very similar spatial patterns (Figure S3). In many locations, the NWS flood thresholds are exceeded only a few times over the entire record, so sensitivity analyses were also performed to determine if the results changed based on the number of years with events exceeding threshold levels. The results were very similar for all tests (Figure S4), so a minimum of 3 years of nonzero events (above a given threshold) was required before fitting a trend (Figure 2). Additionally, not all sites have all four flood categories, and this may affect the spatial patterns of trends (Figures 2, S1, and S3-S5).

For comparison with trends in the number of annual days above flood categories, we also calculate trends in the frequency of flood events above each NWS category. The contributing drainage area A (in logarithmically transformed $\mathrm{mi}^{2}$ ), available from the USGS site inventory for $99 \%$ of our sites, is used as a proxy for the number of days required to produce a peak flow in the basin (hereafter referred to as " $n$-day window"), following an approach similar to Lang et al. [1999] ( $n$-day window $<5$ days $+\log (A)$ ). We use $\log (A)$ following United States Water Resources Council [1981] to allow longer recession times in larger basins. The trend in the number of independent annual flood events (separated by at least one $n$-day window) is also computed using Poisson regression (Figure S5).

\subsection{Precipitation Data}

We use precipitation data to assess whether changes in flood risk are related to rainfall extremes or longterm wetness over the study period. Total daily precipitation data at $\sim 4 \mathrm{~km}$ resolution were obtained from the PRISM Climate Group [2015] and averaged over the contributing basin boundaries from USGS Streamgage NHDPlus Version 1 Basins 2006. Time series were computed for $88 \%$ of sites (i.e., those located in the conterminous USA and with NHDPlus basin boundaries) and tailored to fit the same daily timespan as the gage height data. $P_{\max }$ is the annual maximum precipitation occurring in an $n$-day window for each site (we use $n$-day $=\log (A)$ because precipitation is computed at the basin scale). To find $P_{\text {max }}$ the time series is split into n-day overlapping windows (beginning on each day of the year), in which the total precipitation is aggregated; the window with the largest precipitation total is retained for each year. $P_{\text {annual }}$ reflects total precipitation in each water year. The nonparametric Mann-Kendall test [Mann, 1945 ] is used to identify monotonic temporal trends in $P_{\max }$ and $P_{\text {annual }}$ based on the Kendall rank correlation (accounting for any ties in the data) [McLeod, 2011]. The association between precipitation and the frequency of exceedance of flood stage at each site is quantified by fitting a Poisson regression model between the annual time series of $P_{\text {annual }}$ (predictor) and that of $\mathrm{GH}_{\text {minor }}$ (discrete response variable) if thresholds are exceeded at least 3 times in the entire annual time series (see sensitivity tests for exceedance in Figure S4).

\subsection{Gravity Recovery and Climate Experiment Satellite Data}

NASA's Gravity Recovery and Climate Experiment (GRACE) satellites have been measuring Earth's gravity field anomalies since 2002, providing information on both event flow (precipitation-driven) and base flow (stored 

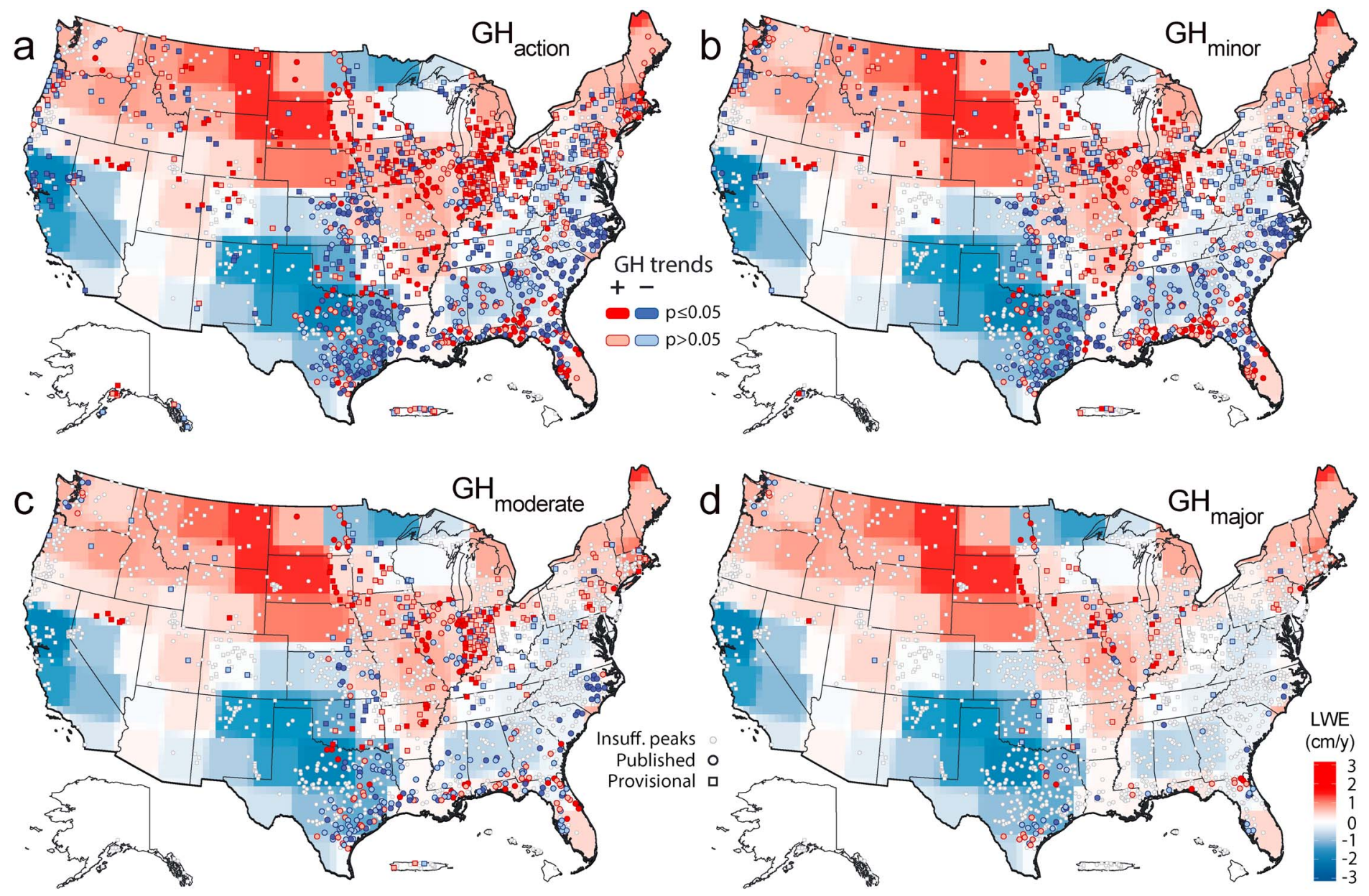

Figure 2. Trends in flood frequency in number of annual days above (a) action, (b) minor, (c) moderate, and (d) major flood NWS categories computed using Poisson regression, alongside trends in GRACE liquid water equivalent thickness in cm/yr (2002-2015). Alaska, Hawaii, and Puerto Rico are shown beneath the continental USA, not to scale. The red circles indicate increasing trends, the blue decreasing trends, and the gray represent sites with insufficient peaks above threshold to compute a trend. The dark symbols indicate significant trends ( $p$-value $\leq 0.05)$; the pale symbols indicate nonsignificant trends $(p$-value $>0.05)$. Sensitivity analyses with other $p$-values and time series lengths are provided in the supporting information. The circles indicate published data from NWIS-web, and the squares indicate provisional data. 

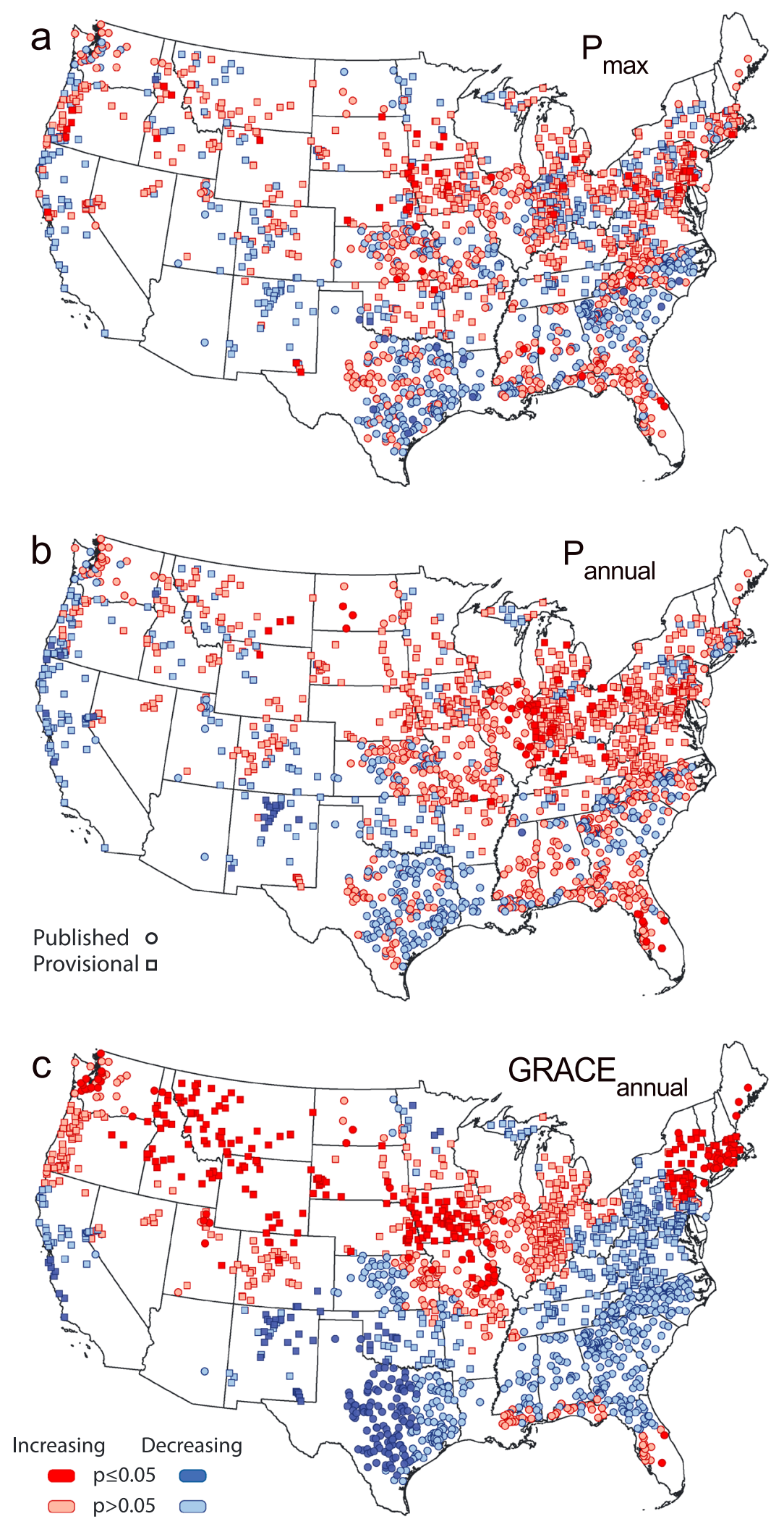

Figure 3. Trends in precipitation and water storage. Maps indicate trends computed using the Mann-Kendall test in basin-averaged (a) $P_{\text {max }}$ (b) $P_{\text {annual, and (c) GRACE }}$ annual (water years). The colors and symbology are the same as in Figure 2. Alaska, Hawaii, and Puerto Rico are not included because of the unavailability of the precipitation data for those locations. 


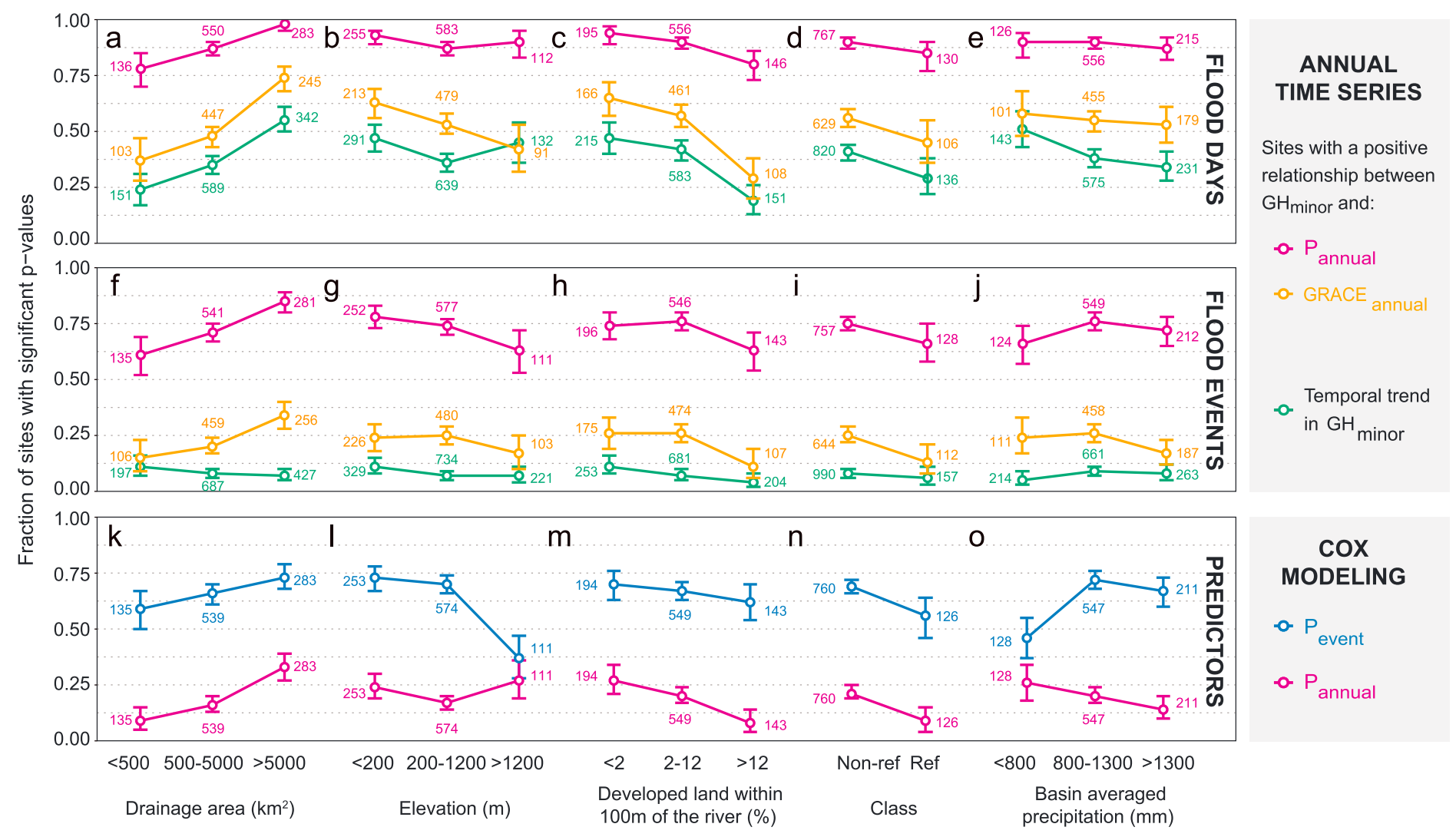

Figure 4. Variables displaying a relationship with trends in flood risk. Predictors from the GAGES-II dataset [Falcone et al., 2010] are shown on the $x$ axis: (a, $f$, and $\mathrm{k}$ ) drainage area $\left(\mathrm{km}^{2}\right) ;(\mathrm{b}, \mathrm{g}$, and $\mathrm{l})$ elevation (mASL); $(\mathrm{c}, \mathrm{h}$, and $\mathrm{m}$ ) developed land within $100 \mathrm{~m}$ of the river (\%); (d, i, and $\mathrm{n})$ class, i.e., whether the site is in a "reference" watershed (with least-disturbed hydrologic conditions) or not; and (e, $\mathrm{j}$, and o) mean annual basin averaged precipitation (mm). Across all panels, the hollow circles indicate the estimated fraction, the intervals represent the 5th and 95th sampling uncertainties, and the numbers refer to the number of sites. The magenta and orange colors indicate the fraction of sites with a significant relationship (at the $5 \%$ level) between $P_{\text {annual }}$ or GRACE annual and the number of days/events above $\mathrm{GH}_{\text {minor }}$ (Figures $4 \mathrm{a}-4 \mathrm{j}$ ). $P_{\text {annual }}$ is summed for each water year in Figures $4 \mathrm{a}-4 \mathrm{j}$ and computed prior to each event in Figures $4 \mathrm{k}-4 \mathrm{o}$ for the Cox modeling. The green colors indicate flood frequency trends computed using the number of flood days (first row) and number of flood events (second row) above $\mathrm{GH}_{\text {minor }}$ every year. Fraction of sites where $P_{\text {event }}$ (blue) and $P_{\text {annual }}$ (magenta) are significant predictors of $\mathrm{GH}_{\text {minor }}$ flood events using Cox regression (Figures $4 \mathrm{k}-40$ ). The numerical $x$ axis variables were binned at approximately the 25th and 75th percentiles of the distributions.

Cox processes, which are a generalization of Poisson processes. While in a Poisson process all the events are considered independent, Cox processes are clustered, so bursts of activity alternate with more quiet periods. For more information and details about Cox processes and regression with time-dependent predictors, consult Cox [1972], Karr [1983], Smith and Karr [1983], Villarini et al. [2013a], and Section S1 in the supporting information. Here we consider two covariates: short-term precipitation prior to a flood event $\left(P_{\text {event }}\right)$ and long-term precipitation $\left(P_{\text {annual, }}\right.$ the sum of all precipitation occurring in the 365 days preceding $\left.P_{\text {event }}\right)$. To compute $P_{\text {event }}$, we first loop through all $\mathrm{GH}_{\text {minor }}$ flood events and calculate the mean number of days that gage height stayed above flood stage before the flood peak (ndays, rounded up to the nearest whole integer). $P_{\text {event }}$ is the sum of all precipitation occurring in a window of ndays plus 10 days preceding the flood event (different window sizes were tested, and we chose the largest value to best distinguish $P_{\text {event }}$ from $P_{\text {annuali }}$ see Figures $\mathrm{S6-S8).} P_{\text {annual }}$ is representative of the overall wetness of the watershed.

Thus, at the resulting 2042 locations (949 published, 1093 provisional) we investigate (i) how the frequency of floods is evolving above the NWS's four flood categories (Figures 1 and 2), (ii) how basin-averaged precipitation and water storage are changing at the same stream gages (Figure 3), and (iii) the factors affecting the trends in flood risk as well as the relationship between gage height and precipitation/antecedent basin wetness (Figure 4). 


\section{Results and Conclusions}

\subsection{Spatial Patterns of Trends in Flood Risk}

Trends in the frequency of flooding above the four NWS flood thresholds computed using Poisson regression reveal a stark contrast between increases in flood risk around the upper Midwest/Great Lakes region and decreases on the Gulf Coastal Plain, the southeastern United States, and California (Figure 2). Broadly speaking, these patterns are similar to the changes in liquid water equivalent measured by NASA's GRACE mission (GRACE $E_{\text {annual, }}$ used here as a proxy for overall basin wetness); two-thirds of $\mathrm{GH}_{\text {minor }}$ and GRACE $\mathrm{E}_{\text {annual }}$ trends exhibit the same sign (Figure S9). This cooccurrence of positive/negative trends in flooding and basin water storage suggests that progressive changes in basin wetness arising from combined climatic and anthropogenic influences precondition the local flood potential [see Reager et al., 2014]. Localized increases in flooding in the Gulf of Mexico, near New Orleans, and selected locations in Florida are also visibly in agreement with GRACE. Flood trends in the western half of the conterminous USA, Alaska, and Puerto Rico show mixed patterns of increases and decreases, while California stands out with almost uniform decreases in flood frequency (Figure 2).

The regional patterns of increasing and decreasing flood risk are broadly similar for all four flood categories but become less similar as the difference between flood levels increases $\left(83 \%\right.$ of $\mathrm{GH}_{\mathrm{action}}$ and $\mathrm{GH}_{\text {minor }}$ trends

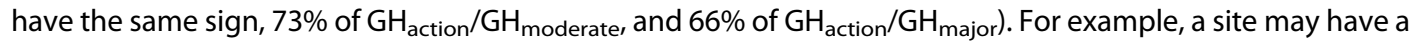
significant increasing trend in $\mathrm{GH}_{\text {action, }}$ but a nonsignificant decreasing trend in $\mathrm{GH}_{\text {major }}$ (see the southernmost sites in Florida). As the moderate and major flood categories are exceeded less frequently than action and minor levels, significant changes are detected at fewer sites (Figure 2), and longer records may be required before trends become significant. We also find a similar spatial distribution of increases versus decreases in flood risk, whether trends are computed using the number of independent annual flood events or with the number of flood days (Figures 2 and S5), and results are consistent across the published and the provisional gage height records (Figure 2). While there may be local differences in river systems that have experienced anthropogenic modifications, the changes in flood frequency that are measured using gage height are largely consistent with previously observed increases in the frequency and magnitude of streamflow across the Midwest [Mallakpour and Villarini, 2015; Slater et al., 2015], the North, and North-East [Milly et al., 2005; Collins, 2009; Slater et al., 2015], as well as decreases in runoff and flood magnitude in the West and Southwest [Milly et al., 2005; Hirsch and Ryberg, 2012] and coastal southeastern regions [Hirsch and Ryberg, 2012] of the United States.

\subsection{The Relationship Between Changing Precipitation, Basin Wetness, and Flood Risk}

Can these trends in flood risk be related to short-term changes in precipitation? While extreme flooding is mostly driven by very heavy rainfall [e.g., Groisman et al., 2001], flood flows often have multiple drivers [Ivancic and Shaw, 2015; Stephens et al., 2015; Berghuijs et al., 2016]; thus, we investigate the relationship between precipitation and stage, and the variables that may modulate it. Using daily precipitation data [PRISM Climate Group, 2015] averaged over each of the contributing basins for the same time periods as the daily gage height data, we computed trends in $P_{\max }$ (the maximum annual precipitation occurring in an $\mathrm{n}$-day floodinducing moving window; see section 2 ) and $P_{\text {annual }}$ (the total annual precipitation) using the Mann-Kendall test. Spatial trends in $P_{\text {annual }}$ and $P_{\max }$ are analogous to longer-term increases in extreme precipitation that have been measured over Central/Midwest/East [Janssen et al., 2014; Villarini et al., 2013b; Mallakpour and Villarini, 2015], Northeast, and Great Lakes [DeGaetano, 2009; Horton et al., 2014] regions, pointing to a generally heightened frequency of high-intensity precipitation days and events [Groisman et al., 2005, 2012; Guilbert et al., 2015]. Decreasing trends are more prominent in the southeastern coastal states of Texas, the Carolinas, and Georgia, and especially over California, where severe water shortages [Diffenbaugh et al., 2015] have resulted in the most severe drought that the U.S. West Coast has seen in centuries (Figures 3a and 3b).

While spatial precipitation trends broadly reflect changing patterns of flood risk, even more notable are the changes in basin-averaged water storage (Figure 3c). Using the same methods as for precipitation, but with shorter time series, we find that increases/decreases in GRACE $E_{\text {annual }}$ are spatially consistent with $P_{\max }$ and $P_{\text {annual }}$ and the distribution of trends in the frequency of flooding (Figures 2, 3, and S9). To quantify this association between basin wetness and flooding, Poisson regression models were fit between the yearly time series of total days exceeding minor flood stage $\left(\mathrm{GH}_{\text {minor }}\right)$ and those of $P_{\text {annual }}$ and GRACE $E_{\text {annual }}$ at each site 
(Figures 4a-4j). The fraction of sites where $\mathrm{GH}_{\text {minor }}$ flood events are significantly related to $P_{\text {annual }}$ is greater than with GRACE $E_{\text {annual }}$ due to longer time series. However, the measured relationships between each of the predictors ( $P_{\text {annual }}$ and $\left.\mathrm{GRACE}_{\text {annual }}\right)$ and $\mathrm{GH}_{\text {minor }}$ are remarkably similar (Figures $4 \mathrm{a}-4 \mathrm{j}$ ) and suggest that broad shifts in basin wetness that occur at the land surface and subsurface over annual time scales (due to climate and human activity) are an important driver of flooding.

If the strength of the relationship between basin wetness (as measured by $P_{\text {annual }} / \mathrm{GRACE}_{\text {annual }}$ ) and $\mathrm{GH}_{\text {minor }}$ (or P-GH coupling) is indeed due to the influence of water storage within the catchment, then we would expect it to be affected by the physical properties that control water retention [Ivancic and Shaw, 2015; Stephens et al., 2015]. Significant P-GH coupling increases markedly in large and low-lying catchments, where there is better integration of flow paths reaching the channel (Figures $4 a, 4 b, 4 f$, and 4g). Locally, P-GH coupling is muted by the presence of impervious land surfaces which disconnect the channel from its floodplain (Figures 4c and 4h); however, at the catchment scale, anthropogenic alterations to water storage, which modify/sustain specific flow pathways, appear to have amplified the climate signal in river flows in comparison with less-modified sites (Figures 4d, 4i, and 4n) (as in Vogel et al. [2011]). Last, we find that the strongest P-GH coupling occurs when climates are neither too wet nor too dry (Figures $4 \mathrm{e}, 4 \mathrm{j}$, and 40 ).

To further assess the dependence of flooding on basin wetness, we modeled the occurrence of individual $\mathrm{GH}_{\text {minor }}$ flood events as a function of the precipitation occurring immediately before the flood $\left(P_{\text {event }}\right)$ and of the annual wetness $\left(P_{\text {annual }}\right)$ using Cox regression (Figures 4k-4o) [e.g., Villarini et al., 2013a]. While $P_{\text {event }}$ tends to be a significant predictor more than half of the time, and across all types of sites, $P_{\text {annual }}$ is also an important predictor, especially in large or dry catchments with unurbanized riparian areas (Figures 4, S7, and S8). In other terms, locations with greater potential water storage are more sensitive to year-to-year fluctuations in basin wetness, and it is to be expected that the inclusion of the $P_{\text {annual }}$ predictor will substantially improve the prediction of flooding in these locations.

In sum, in a warming world where changes in the spatial and temporal distributions of precipitation and large-scale climate indices are affecting the magnitude and frequency of high flows [Groisman et al., 2001; Karl et al., 2009; Mallakpour and Villarini, 2015, 2016], our findings reveal that there are actually strong regional patterns of changing flood risk which can be assessed and communicated from a practical standpoint in terms of the local threat to people and assets. These regional patterns are preconditioned by overall basin wetness, especially in low-lying areas with notable water storage. Thus, any projections of changes in flood risk above the action, minor, moderate, and major flood categories based on the observed amplification of precipitation extremes should most certainly take into account the short-term, concomitant changes in basin wetness resulting from broad-scale shifts in climate and water management.

\section{Acknowledgments}

We are extremely grateful to the USGS for collecting and providing us with the gage height data (see Table S1). This work would not have been possible without their efforts. This material is based upon work supported by the Broad Agency Announcement Program and the Engineer Research and Development Center-Cold Regions Research and Engineering Laboratory under Contract W913E5-16-C-0002, IIHR-Hydroscience and Engineering, the lowa Flood Center, the USACE Institute for Water Resources (G.V.), and the National Science Foundation under CAREER Grant AGS-1349827 (G.V.). We gratefully acknowledge the suggestions and comments by Rhawn Denniston (Cornell College) and those made by anonymous reviewers. The authors declare no competing financial interests. Correspondence and requests for materials should be addressed to L.J.S. (louise-slater@uiowa.edu).

\section{References}

Archfield, S., R. Hirsch, A. Viglione, and G. Blöschl (2016), Fragmented patterns of flood change across the United States, Geophys. Res. Lett., 43, 10,232-10,239, doi:10.1002/2016GL070590.

Berghuijs, W. R., R. A. Woods, C. J. Hutton, and M. Sivapalan (2016), Dominant flood generating mechanisms across the United States, Geophys. Res. Lett., 43, 4382-4390, doi:10.1002/2016GL068070.

Carter, R. W., and J. Davidian (1968), Chapter A6 - General procedure for gaging streams, Book 3- Applications of hydraulics, in Techniques of Water Resources Investigations of the USGS, pp. 1-13, US Gov't. Print. Off., Books and Open File Rep. Sect., U.S. Geol. Surv., Denver, Colo.

Collins, M. J. (2009), Evidence for changing flood risk in New England since the late 20th century, JAWRA J. Am. Water. Resour. Assoc., 45(2), 279-290, doi:10.1111/j.1752-1688.2008.00277.x.

Cox, D. R. (1972), Regression models and life tables (with discussion), J. R. Stat. Soc. Ser. B, 34, 187-220.

Diffenbaugh, N. S., D. L. Swain, and D. Touma (2015), Anthropogenic warming has increased drought risk in California, Proc. Natl. Acad. Sci. U.S.A., 112, 3931-3936, doi:10.1073/pnas.1422385112.

DeGaetano, A. T. (2009), Time-dependent changes in extreme-precipitation return-period amounts in the continental United States, J. Appl. Meteorol. Climatol., 48(10), 2086-2099, doi:10.1175/2009JAMC2179.1.

Falcone, J. A., D. M. Carlisle, D. M. Wolock, and M. R. Meador (2010), GAGES: A stream gage database for evaluating natural and altered flow conditions in the conterminous United States, Ecology, 91(2), 621-621.

Groisman, P. Y., R. W. Knight, and T. R. Karl (2001), Heavy precipitation and high streamflow in the Contiguous United States: Trends in the twentieth century, Bull. Am. Meteorol. Soc., 82(2), 219-246, doi:10.1175/1520-0477(2001)082<0219:HPAHSI>2.3.CO;2.

Groisman, P. Y., R. W. Knight, D. R. Easterling, T. R. Karl, G. C. Hegerl, and V. N. Razuvaev (2005), Trends in intense precipitation in the climate record, J. Clim., 18(9), 1326-1350, doi:10.1175/JCLI3339.1.

Groisman, P. Y., R. W. Knight, and T. R. Karl (2012), Changes in intense precipitation over the Central United States, J. Hydrometeorol., 13(1), 47-66, doi:10.1175/JHM-D-11-039.1.

Guilbert, J., A. K. Betts, D. M. Rizzo, B. Beckage, and A. Bomblies (2015), Characterization of increased persistence and intensity of precipitation in the northeastern United States, Geophys. Res. Lett., 42, 8888-1893, doi:10.1002/2015GL063124. 
Horton, R., G. Yohe, W. Easterling, R. Kates, M. Ruth, E. Sussman, A. Whelchel, D. Wolfe, and F. Lipschultz (2014), Ch. 16: Northeast, Climate change impacts in the United States, in The Third National Climate Assessment, pp. 371-395, U.S. Global Change Research Program, Washington, D. C., doi:10.7930/J0SF2T3P.

Hirsch, R. M., and K. R. Ryberg (2012), Has the magnitude of floods across the USA changed with global $\mathrm{CO}_{2}$ levels?, Hydrol. Sci. J., 57(1), 1-9, doi:10.1080/02626667.2011.621895.

Ivancic, T. J., and S. B. Shaw (2015), Examining why trends in very heavy precipitation should not be mistaken for trends in very high river discharge, Clim. Change, 133(4), 681-693, doi:10.1007/s10584-015-1476-1.

Janssen, E., D. Wuebbles, and K. Kunkel (2014), Observational and model based trends and projections of extreme precipitation over the Contiguous United States, Earth's Future, 1-15, doi:10.1002/2013EF000185.

Jha, A. K., R. Bloch, and J. Lamond (2012), Cities and flooding: A guide to integrated urban flood risk management for the 21st century, World Bank Publications, Washington, D. C. [Available at http://bit.ly/1THINWz.]

Karl, T. R., J. M. Melillo, and T. C. Peterson (Eds.) (2009), Global climate change impacts in the United States. A State of Knowledge Report from the U.S. Global Change Research Program, Cambridge Univ. Press, New York. [Available at www.globalchange.gov/usimpacts.]

Karr, A. F. (1983), Point Processes and Their Statistical Inference, Dekker, New York (1991).

Kousky, C., and E. Michel-Kerjan (2015), Examining flood insurance claims in the United States: Six key findings, J. Risk Insur., doi:10.1111/ jori.12106.

Lang, M., T. B. M. J. Ouarda, and B. Bobée (1999), Towards operational guidelines for over-threshold modeling, J. Hydrol., 225, $103-117$.

Mallakpour, I., and G. Villarini (2015), The changing nature of flooding across the central United States, Nature Climate Change, 1-5, doi:10.1038/NCLIMATE2516.

Mallakpour, I., and G. Villarini (2016), Investigating the relationship between the frequency of flooding over the central United States and large-scale climate, Adv. Water Resour., 92, 159-171.

Mann, H. B. (1945), Nonparametric tests against trend, Econometrica, 13, 245-249.

McLeod, A. I. (2011), Kendall: Kendall rank correlation and Mann-Kendall trend test. R package version 2.2. [Available at https://CRAN.Rproject.org/package=Kendall.]

Merz, B., Z. W. Kundzewicz, J. Delgado, Y. Hundecha, and H. Kreibich (2012), Detection and attribution of changes in flood hazard and risk, in Changes in Flood Risk in Europe, pp. 435-458.

Milly, P. C. D., R. T. Wetherald, K. A. Dunne, and T. L. Delworth (2002), Increasing risk of great floods in a changing climate, Nature, 415(6871), 514-517, doi:10.1038/415514a.

Milly, P. C. D., K. A. Dunne, and A. V. Vecchia (2005), Global patterns of trends in streamflow and water availability in a changing climate, Nature, 438, 347-350, doi:10.1038/nature04312.

PRISM Climate Group (2015), Oregon State Univ. [Available at http://prism.oregonstate.edu.]

NOAA National Weather Service (2012), NWS Manual 10-950. Definitions and General Terminology. Hydrological Services Program, NWSPD 10-9. [Available at: http://www.nws.noaa.gov/directives/sym/pd01009050curr.pdf.]

Reager, J. T., B. F. Thomas, and J. S. Famiglietti (2014), River basin flood potential inferred using GRACE gravity observations at several months lead time, Nat. Geosci., 7(8), 588-592, doi:10.1038/ngeo2203.

Slater, L. J., M. B. Singer, and J. W. Kirchner (2015), Hydrologic versus geomorphic drivers of trends in flood hazard, Geophys. Res. Lett., 42, 1-7, doi:10.1002/2014GL062482.

Slater, L. J. (2016), To what extent have changes in channel capacity contributed to flood hazard trends in England and Wales?, Earth Surf. Process. Landf., doi:10.1002/esp.3927.

Smith, J. A., and A. F. Karr (1983), A point process model of summer season rainfall occurrences, Water Resour. Res., 19(1), 95-103, doi:10.1029/ WR019i001 p00095.

Stephens, E., J. J. Day, F. Pappenberger, and H. Cloke (2015), Precipitation and floodiness, Geophys. Res. Lett., 42, 370-376, doi:10.1002/ 2015 GL066779.

Stover, S., and D. R. Montgomery (2001), Channel change and flooding, Skokomish River, Washington, J. Hydrol., 243(3-4), 272-286, doi:10.1016/S0022-1694(00)00421-2.

United States Geological Survey (2015), USGS Surface-Water Data for the Nation. [Available at http://waterdata.usgs.gov/nwis/sw.]

United States Water Resources Council (1981), Guidelines for determining flood flow frequency, Bulletin 17B, U.S. Water Resources Council, 29, 1-194.

Villarini, G., J. A. Smith, R. Vitolo, and D. B. Stephenson (2013a), On the temporal clustering of US floods and its relationship to climate teleconnection patterns, Int. J. Climatol., 33(3), 629-640.

Villarini, G., J. A. Smith, and G. A. Vecchi (2013b), Changing frequency of heavy rainfall over the central United States, J. Clim., 26(1), 351-357, doi:10.1175/JCLI-D-12-00043.1.

Vogel, R. M., C. Yaindl, and M. Walter (2011), Nonstationarity: Flood magnification and recurrence reduction factors in the United States, J. Am. Water Resour. Assoc., 47(3), 464-474, doi:10.1111/j.1752-1688.2011.00541.x.

Watkins, M. M., D. N. Wiese, D.-N. Yuan, C. Boening, and F. W. Landerer (2015), Improved methods for observing Earth's time variable mass distribution with GRACE using spherical cap mascons, J. Geophys. Res. Solid Earth, 120, 2648-2671, doi:10.1002/2014JB011547. 